\title{
Interferon-gamma inhibits adenosine A2A receptor function in hepatic stellate cells by STATI-mediated repression of adenylyl cyclase
}

This article was published in the following Dove Press journal: International Journal of Interferon, Cytokine and Mediator Research 12 October 2010

Number of times this article has been viewed

\section{Eric T Block \\ Bruce N Cronstein}

Department of Medicine, New York University School of Medicine, NY, USA
Correspondence: Bruce N Cronstein Department of Medicine, New York University School of Medicine, 550 First Ave, New York, NY 10016, USA Tel + I 2122636275

Fax + I 2122636275

Email cronsb0I@med.nyu.edu.
Background and purpose: Adenosine, an endogenous purine nucleoside, is a potent regulator of the inflammatory response and stimulus for fibrosis. We have previously demonstrated that adenosine, acting at the A2A receptor, plays a central role in hepatic fibrosis via direct promotion of collagen production by hepatic stellate cells. As we have previously demonstrated that macrophage A2A receptor function is regulated by interferon-gamma (IFN $\gamma$ ), a noted antifibrotic but pro-inflammatory cytokine, we examined its effect on A2AR-stimulated collagen production in the human hepatic stellate cell line LX-2.

Experimental approach: Collagen expression was determined by western blotting and realtime reverse transcription polymerase chain reaction (RT-PCR). Receptor desensitization was assessed by western blotting for membrane associated GRK2. Receptor signaling was determined by western blotting for phosphorylated extracellular signal-related protein kinase (ERK) protein and immunoassay for intracellular cyclic AMP (cAMP). siRNA was used to knock down expression of adenylyl cyclase and signal transducer and activator of transcription (STAT). Adenylyl cyclase expression was assessed by realtime RT-PCR, and STAT expression was assessed by western blotting.

Key results: $\mathrm{IFN} \gamma$ diminishes $\mathrm{A} 2 \mathrm{~A}$ receptor-mediated collagen production at both protein and mRNA levels. IFN $\gamma$ alters signal transduction at A2A receptors by a STAT1 mediated mechanism involving the suppression of adenylyl cyclase expression.

Conclusions and implications: IFN $\gamma$ inhibits the function of the adenosine A2A receptor in hepatic stellate cells by downregulating the expression of adenylyl cyclase. This finding explains, at least in part, the protective effect of IFN $\gamma$ in hepatic fibrosis.

Keywords: hepatic fibrosis, collagen-1, interferon-gamma, inflammation, adenylyl cyclase, siRNA, hepatic stellate cells

\section{Introduction}

Adenosine is a purine nucleoside released during times of cellular stress. ${ }^{1}$ Adenine nucleotide release is the major source of extracellular adenosine, ${ }^{2}$ which regulates inflammation, ${ }^{3,4}$ cholesterol metabolism, ${ }^{5}$ wound healing ${ }^{6}$ and fibrosis, ${ }^{7}$ etc, via interaction with cell surface receptors. There are 4 known mammalian adenosine receptors: A1, A2A, A2B, and A3, all of which belong to the G-protein coupled receptor (GPCR) family. ${ }^{8,9}$ Expression of these receptors varies among cell types and is regulated by multiple factors. ${ }^{1}$ External factors,${ }^{10}$ receptor localization,,${ }^{11}$ and sensitization ${ }^{12}$ all play a role in the functional regulation of adenosine receptors.

Previous work by our laboratory and others has shown that the inflammatory cytokines interferon-gamma (IFN $\gamma)$, tumor necrosis factor alpha (TNF $\alpha)$, and interleukin-1 
(IL-1) regulate $\mathrm{A} 2 \mathrm{~A}$ receptor expression and function in monocytes. ${ }^{13}$ IFN $\gamma$ is a negative regulator of function; while TNF $\alpha$ and IL-1 increase A2A receptor expression and enhance function by impairing desensitization of the A2A receptor. ${ }^{14}$ TNF $\alpha$ and IL-1 block desensitization by preventing G-protein coupled receptor kinase 2 (GRK2) and $\beta$-arrestin association with the membrane in a sphingomyelinase-dependent manner. ${ }^{14}$ The mechanism by which IFN $\gamma$ inhibits A2A receptor function remains unknown. It is also undetermined whether or not IFN $\gamma$ inhibits A2A receptor function in other cell types besides monocytes.

Adenosine plays an important role in the development of multiple forms of fibrosis, including hepatic fibrosis. Adenosine A2A receptor (A2AR) expression is upregulated in liver homogenates from mice and humans with hepatic fibrosis, and protection from fibrosis has been observed in A2A receptor knockout mice. ${ }^{15,16}$ Adenosine also regulates chemotaxis in hepatic stellate cells, ${ }^{17}$ and recent work in our laboratory has demonstrated that activation of the A2A receptor provides a pro-fibrotic signal to these cells. ${ }^{18}$ Furthermore, we have observed that adenosine, generated extracellularly from adenine nucleotides, plays a critical role in the pathogensis of hepatic fibrosis in vivo. ${ }^{17}$

Therefore, we examined the effect of IFN $\gamma$ on A2A receptor function in LX-2 cells, a human hepatic stellate cell line. ${ }^{19}$ We observed that IFN $\gamma$ has the same negative effect on adenosine receptor signaling and function, particularly collagen production, in human hepatic stellate cells as it does in monocytes. ${ }^{13}$ We further demonstrated that IFN $\gamma$ downregulates adenylyl cyclase expression, which is required for $\mathrm{A} 2 \mathrm{~A}$ receptor-mediated regulation of collagen production. We conclude that IFN $\gamma$ inhibits the function of the A2AR in hepatic stellate cells by downregulating the expression of adenylyl cyclase.

\section{Materials and methods Materials}

Materials were as follows: cAMP Biotrak Enzymeimmunoassay System (GE Healthcare, Amersham UK), GRK2 Antibody (Santa Cruz Biotechnology, Santa Cruz, CA, USA), BetaActin Antibody (Abcam), Anti-Type 1 Collagen Antibody (Southern Biotech, Birmingham, AL, USA), anti-phosphoERK1 \& 2 (extracellular signal-related protein kinases 1 and 2) Antibody (Biosource - now Invitrogen, Carlsbad, CA, USA), Anti-ERK1 \& 2 pan Antibody (Biosource), recombinant human IFN $\gamma$ (R\&D Systems, Minneapolis, MN, USA), Recombinant Human TNF $\alpha$ (R \& D Systems), recombinant human tumor growth factor beta 1 (TGF- $\beta 1$ ) (R \& D Systems),
CGS 21680 Hydrochloride (Tocris Bioscience, Ellisville, MO, USA), Stellate Cell Growth Supplement (ScienCell Research Laboratories, San Diego, CA, USA), 10× Cell Lysis Buffer (Cell Signaling, Beverly, MA, USA), Brilliant SYBR Green QPCR Master Mix (Stratagene), BCA Assay (Pierce, Rockford IL, USA), Mission Transduction Particles NM_003150, NM_007315, NM_004036, NM_001114, and NM_001116 (Sigma-Aldrich, St. Louis, MO, USA). The LX-2 human hepatic stellate cell line was characterized and provided by Dr SL Friedman from Mount Sinai Medical School, NY, USA. ${ }^{19}$

\section{Cell culture}

LX-2 human hepatic stellate cells were grown in T75 size tissue culture flasks in Dulbecco's modified eagle medium (DMEM) supplemented with 10\% fetal bovine serum, 1\% penicillin/streptomycin, and $1 \% \mathrm{~L}$-glutamine at $37^{\circ} \mathrm{C}$ in a humidified atmosphere containing 5\% $\mathrm{CO}_{2}$. Trypsin was used to re-plate cells into T25 flasks or 6-well or 24-well tissue culture plates for experiments. Experiments requiring serum-free media were conducted using DMEM supplemented with $1 \%$ penicillin/streptomycin, 1\% L-glutamine, and $1 \%$ stellate cell growth serum (SteCGS) instead of $10 \%$ fetal bovine serum.

\section{RNA interference}

Viral particles expressing siRNA sequences against AC3, AC9, STAT1, and STAT3 were purchased commercially from Sigma-Aldrich (see Materials). Viral particles were independently verified for efficacy and specificity by SigmaAldrich. $3 \times 10^{4}$ LX-2 cells were plated into 6-well tissue culture plates. 24 hours later, cells were treated with $8 \mu \mathrm{g}$ hexadimethrine bromide per $\mathrm{mL}$ of medium. Viral particles were added immediately at suitable multiplicities of infection (MOI) according to manufacturer's instructions. The following day, medium containing viral particles was removed and cells were washed $1 \times$ with phospho-buffered saline $(\mathrm{PBS})$ and incubated in fresh cDMEM. 24 hours later, medium was replaced with cDMEM containing $10 \mu \mathrm{g} / \mathrm{mL}$ puromycin for selection of transduced cells. Cells were grown in puromycin containing medium (replaced every 3-4 days) for 10 days to 2 weeks until resistant colonies could be identified. Resistant colonies were expanded and used in experiments.

\section{Protein extraction}

Cells were grown in T25 flasks until 80\%-90\% confluent. Media was removed and cells were washed with PBS. Media was replaced with serum-free DMEM. Cytokines were added to each flask, and cells were incubated overnight for 
18-24 hours. Following overnight incubation, CGS21680 (final concentration $1 \mu \mathrm{M}$ ) or $1 \mathrm{ng} / \mathrm{mL} \mathrm{TGF}-\beta 1$ (final concentration 1) was added, and cells were incubated again. To measure collagen production, cells were incubated for 24 hours. To measure GRK2 translocation, cells were incubated for 10 minutes. To measure ERK1/2 phosphorylation, cells were incubated for 5 minutes. To measure STAT expression, cells were left untreated in complete DMEM in T25 flasks. Each separate experiment consisted of individual flasks receiving different combinations of cytokines and CGS21680 or TGF- $\beta 1$. Controls were given DMSO or buffer instead of cytokines or CGS21680 or TGF- $\beta 1$, as appropriate. Each flask resulted in a single sample. Each sample was run multiple times on SDS-PAGE gels and results were averaged to give a result for that experiment. $\mathrm{N}$ values in the data reflect repetition of each separate experiment.

To prepare whole cell lysates, cells were washed once with PBS and incubated on a rocker for 1 hour with 200-300 $\mu \mathrm{L}$ cell lysis buffer plus protease inhibitors per T25 flask at $4^{\circ} \mathrm{C}$. After the incubation, plates were scraped and the lysates transferred to a microcentrifuge tube on ice. Tubes were centrifuged at $10,000 \mathrm{rpm}$ for 10 minutes at $4^{\circ} \mathrm{C}$. Supernatants containing whole cell extract were transferred to a clean microcentrifuge tube on ice. Pellets were discarded. Protein concentration in extracts was determined by a standard BCA assay according to the manufacturer's instructions. Samples were then run on an SDS-PAGE gel or frozen at $-20^{\circ} \mathrm{C}$ for later use.

To prepare crude membrane fractions, cells were washed once with PBS and incubated with trypsin for 5 minutes. Cells were transferred to microcentrifuge tubes and pelleted by a 30 second pulse in a microcentrifuge, then washed once with PBS and pelleted again. Cells were resuspended in $500 \mu \mathrm{L}$ ice-cold PBS with protease inhibitor and left on ice. Each tube was sonicated 3 times at maximum level for 8-10 seconds each time. Cells were left on ice for 15-20 seconds in between each sonication. After sonication, tubes were centrifuged at $300 \times g$ for 10 minutes at $4^{\circ} \mathrm{C}$. Supernatant was transferred to another ice-cold tube, and the remaining pellets were discarded. To isolate membrane protein, the tubes were centrifuged at maximum speed for 30 minutes at $4^{\circ} \mathrm{C}$. Supernatant containing the cytosolic fraction of the cells was removed and discarded, or saved by freezing at $-80^{\circ} \mathrm{C}$. The pellet was resuspended in $100 \mu \mathrm{L}$ ice-cold PBS plus protease inhibitors and stored at $-80^{\circ} \mathrm{C}$. Protein concentrations were determined by a standard BCA assay according to the manufacturer's instructions. Samples were then run on an SDS-PAGE gel or frozen at $-20^{\circ} \mathrm{C}$ for later use.

\section{Western blotting}

Equal amounts of protein $(8-40 \mu \mathrm{g} /$ lane $)$ were separated on a $7.5 \%$ or $10 \%$ SDS-PAGE gel as appropriate and transferred to nitrocellulose membranes. Membranes were stained with Ponceau to confirm effective transfer, then blocked for 2 hours rocking at room temperature in tris-buffered saline (TBST) containing either 3\% bovine serum albumin (for phospho-proteins) or 5\% dry milk. Blots were then incubated overnight rocking at $4^{\circ} \mathrm{C}$ with primary antibody diluted in blocking buffer to the manufacturer's recommended concentration. Blots were washed 3-4 times with TBST and incubated for 2 hours rocking at room temperature with alkaline phosphatase or horseradish peroxidase conjugated secondary antibody. Blots were again washed 3-4 times with TBST and exposed for 5 minutes to either enhanced chemifluorescence (ECF) or enhanced chemiluminescence (ECL) substrate. ECF exposed blots were scanned using the Storm 860 Phosphoimager, while ECL exposed blots were imaged using the Gel Logic 2200 Imaging System. Band intensity was quantitated using Molecular Imaging or ImageQuant software. To screen for another protein, blots were stripped after imaging and re-probed.

\section{RNA extraction}

Cells were grown in T25 flasks until 80\%-90\% confluent. Media was removed and cells were washed with PBS. Media was replaced with serum-free DMEM. IFN $\gamma$ was added to each flask, and cells were incubated for 4,12 , or 24 hours. Control cells were not incubated with IFN $\gamma$. Each separate experiment consisted of individual flasks receiving IFN $\gamma$ (or buffer as control) for a different length of time. Each flask resulted in a single sample. Each sample was analyzed by realtime reverse transcription polymerase chain reaction (RTPCR) in duplicate or triplicate and results were averaged to give a result for that experiment. $\mathrm{N}$ values in the data reflect repetition of each separate experiment.

To isolate total cellular RNA, cells were washed once with PBS and incubated in $2 \mathrm{~mL}$ Trizol per T25 flask. Trizol was added directly to the flasks, and flasks were incubated at $37^{\circ} \mathrm{C}$ for 5 minutes. Supernatant was transferred to microcentrifuge tubes ( 2 tubes per plate, $1 \mathrm{~mL}$ per tube) and frozen at $-80^{\circ} \mathrm{C}$ or used immediately. If frozen, samples were thawed and incubated for at least 5 minutes at room temperature to dissociate of nucleoprotein complexes. $200 \mu \mathrm{L}$ of chloroform was added to each tube, tubes were vortexed briefly and incubated at room temperature for 3 minutes, and were then centrifuged at $12,000 \times g$ for 15 minutes at $4^{\circ} \mathrm{C}$. Following centrifugation, the mixture 
was separated into a lower, red organic phase and an upper, clear, aqueous phase. RNA remained in the aqueous phase. The upper, clear, aqueous phase was transferred by pipet to a new tube. $500 \mu \mathrm{L}$ of isopropanol was added to the tube, tubes were vortexed and incubated at room temperature for 10 minutes, and were then centrifuged at $12,000 \times g$ for 15 minutes at $4^{\circ} \mathrm{C}$. Following centrifugation, the RNA formed a gel-like pellet on the side/bottom of the tube. Supernatant was removed and pellet washed with $1 \mathrm{~mL}$ of $75 \%$ ethanol by vortexing briefly and centrifuging at no more than $7,500 \times g$ for 5 minutes at $4^{\circ} \mathrm{C}$. Supernatant was again removed, and pellet air dried. RNA was redissolved in $8 \mu \mathrm{L}$ of RNase-free water by pipetting, like tubes were combined, and RNA was incubated for 10 minutes at $55^{\circ} \mathrm{C}-60^{\circ} \mathrm{C}$. Following incubation, RNA concentration was determined. RNA was stored at $-80^{\circ} \mathrm{C}$ unless used immediately in reverse transcriptase reaction.

\section{Realtime RT-PCR}

cDNA was reverse transcribed from $3.0 \mu \mathrm{g}$ mRNA in a $50 \mu \mathrm{L}$ reaction containing $\mathrm{MgCl}_{2}, 10 \mathrm{X}$ buffer, dNTPs, RNase inhibitor, reverse transcriptase, and a poly $(\mathrm{t})$ primer to ensure only mRNA was transcribed. The reaction occurred over 1 hour at $45^{\circ} \mathrm{C}$. The resultant cDNA was amplified in a spectrofluorometric thermal cycler (Stratagene, Cedar Creek, TX, USA) using Brilliant SYBR Green QPCR Master Mix (Stratagene cat\# 600548) according to the manufacturer's instructions. mRNA levels were standardized using amplification of the housekeeping gene glyceraldehyde 3-phosphate dehydrogenase (GAPDH), whose consistency was confirmed by amplification of the housekeeping gene $\beta$-actin. PCR primer sequences for adenylyl cyclase isoforms were previously published by Kolachala et al. ${ }^{20}$ GAPDH primer sequences are: CATCATCCCTGCCTCTAC (sense) and 5' CCTGTTGCTGTAGCCAAAT (antisense).

To quantitate expression of all 9 adenylyl cyclase isoforms, mRNA was denatured at $95^{\circ} \mathrm{C}$ for 15 minutes, then amplified using 45 cycles of denaturation $\left(95^{\circ} \mathrm{C}\right.$ for 30 seconds), annealing $\left(60^{\circ} \mathrm{C}\right.$ for 30 seconds), and extension $\left(72^{\circ} \mathrm{C}\right.$ for 1 minute). SYBR green fluorescence was measured at the end of each extension step, $\mathrm{C}(\mathrm{t})$ values were calculated for each curve, and relative expression levels quantitated using the following formula: fold increase $=2^{\wedge}[$ (goi control - hkg control) - (goi stimulated - hkg stimulated)], where 'goi' represents the gene of interest and 'hkg' represents the housekeeping gene GAPDH. Specificity of the final products was determined by melting curve analysis and gel electrophoresis. After amplification, a final melting curve was recorded by denaturating the products $\left(95^{\circ} \mathrm{C}\right.$ for 1 minute), cooling the PCR mixture to $55^{\circ} \mathrm{C}$ for 30 seconds, and then slowly heating it to $95^{\circ} \mathrm{C}$ at 30 seconds. SYBR green fluorescence was measured continuously during the heating step. Products were run on a $2 \%$ agarose gel stained with ethidium bromide. The size of the products on the gel matched the calculated size.

\section{Cyclic AMP (cAMP) quantification}

Cells were plated in a 24-well tissue culture plate and treated according to manufacturer's instructions for the Amersham cAMP Biotrak Enzymeimmunoassay System (GE Healthcare cat\#RPN225). 24 hours after cells were plated, media was removed and cells were washed with PBS. Media was replaced with serum-free DMEM, cytokines were added to each flask, and cells were incubated overnight for 18-24 hours. Following overnight incubation, CGS21680 (final concentration $1 \mu \mathrm{M}$ ) was added, and cells were incubated for 2, 5, 10, or 20 minutes. Each separate experiment consisted of 4 replicate 24-well plates. Each well received a different combination of cytokines and CGS21680 (not all wells were used in each experiment). Controls were given DMSO or buffer instead of cytokines or CGS21680, as appropriate. All 4 replicates were run multiple times on SDS-PAGE gels, and results were averaged to give a result for that experiment. $\mathrm{N}$ values in the data reflect repetition of each separate experiment.

Immediately following incubation, plates were placed on ice. Supernatants were removed, and cells were washed with ice-cold PBS. Intracellular cAMP levels were determined according to the manufacturer's instructions for the Amersham cAMP Biotrak Enzymeimmunoassay System (GE Healthcare cat\#RPN225), with the following changes: samples were frozen after lysis and thawed before application to the manufacturer's 96-well plate, and the final colormetric reaction was stopped after approximately 15 minutes according to kit instructions. cAMP concentrations were normalized to protein content of each sample by performing a BCA assay with leftover samples in the manufacturer's lysis buffer.

\section{Statistical analysis}

Statistical analysis was performed using GraphPad Prism and Statmate software (GraphPad Software, Inc., San Diego, CA, USA). Data is presented as mean \pm standard error of the mean where appropriate. ANOVA and $t$-test were used to determine statistical significance; differences with a $P$ value under 0.05 were considered significant. 


\section{Results}

IFN $\gamma$ impairs the ability of the A2AR specific agonist CGS21680 to induce collagen production in hepatic

\section{stellate cells}

We have previously reported that the $\mathrm{A} 2 \mathrm{~A}$ receptor specific agonist CGS21680 induces collagen production in primary human hepatic stellate cells as well as the LX-2 human hepatic stellate cell line in a concentration-dependent manner. ${ }^{18}$ Since IFN $\gamma$ has been shown to inhibit A2A receptor function in other cell lines, ${ }^{13}$ we examined the ability of IFN $\gamma$ to inhibit $\mathrm{A} 2 \mathrm{~A}$ receptor stimulation of collagen production in LX-2 cells. CGS21680 increased collagen-1 protein production $(21 \% \pm 5 \%$ increase relative to control, $P<0.05, \mathrm{n}=7$ ). The presence of TNF $\alpha$ enhanced CGS21680-mediated stimulation of collagen-1 protein production $(37 \% \pm 18 \%$ increase relative to control, $P<0.05, \mathrm{n}=5$ ) while in the presence of IFN $\gamma$ the A2A receptor agonist did not stimulate collagen-1 protein production ( $8 \% \pm 4 \%$ decrease relative to control, $P=$ n.s., $\mathrm{n}=7$ ) (Figure 1A).

A
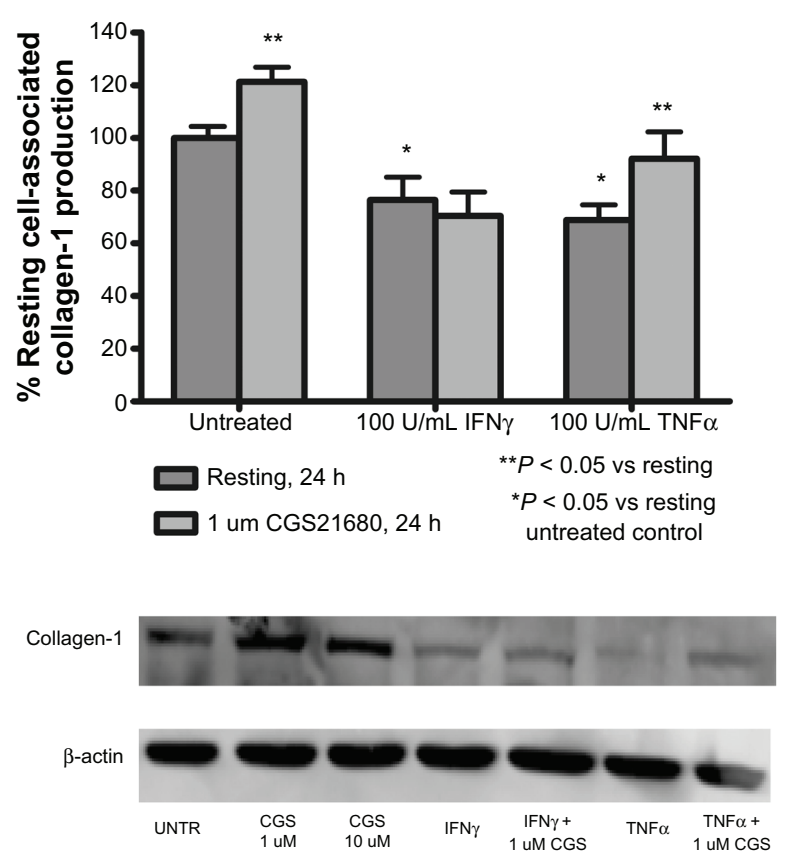

Since both IFN $\gamma$ and TNF $\alpha$ affect basal collagen production in LX-2 cells, we determined whether the effects of IFN $\gamma$ and TNF $\alpha$ on $\mathrm{A} 2 \mathrm{~A}$ receptor mediated collagen production were specific by measuring the effect of IFN $\gamma$ and TNF $\alpha$ treatment on TGF- $\beta 1$ induced collagen- 1 production. As expected, TGF- $\beta 1$ increased collagen- 1 production $(44 \%$ $\pm 3 \%$ increase relative to control, $P<0.05, \mathrm{n}=3$ ). The effect of TGF- $\beta 1$ on collagen production was unaffected by TNF $\alpha$ $(45 \% \pm 21 \%$ increase relative to control, $P<0.05, \mathrm{n}=5)$ and $\operatorname{IFN} \gamma(52 \% \pm 22 \%$ increase relative to control, $P<0.05$, $\mathrm{n}=3$ ) (Figure 1B). Thus, IFN $\gamma$ specifically inhibits A2A receptor mediated collagen production in LX-2 cells. Both IFN $\gamma$ and TNF $\alpha$ impair basal collagen-1 production in LX-2 cells, consistent with previous results in the literature. ${ }^{21}$

\section{IFN $\gamma$ impairs the ability of CGS2 1680 to induce ERK phosphorylation \\ in hepatic stellate cells}

Our laboratory recently characterized the downstream signaling pathway that leads to $\mathrm{A} 2 \mathrm{~A}$ receptor mediated collagen production in LX-2 cells ${ }^{18}$ (Figure 2A). Canonical G-protein

\section{B}
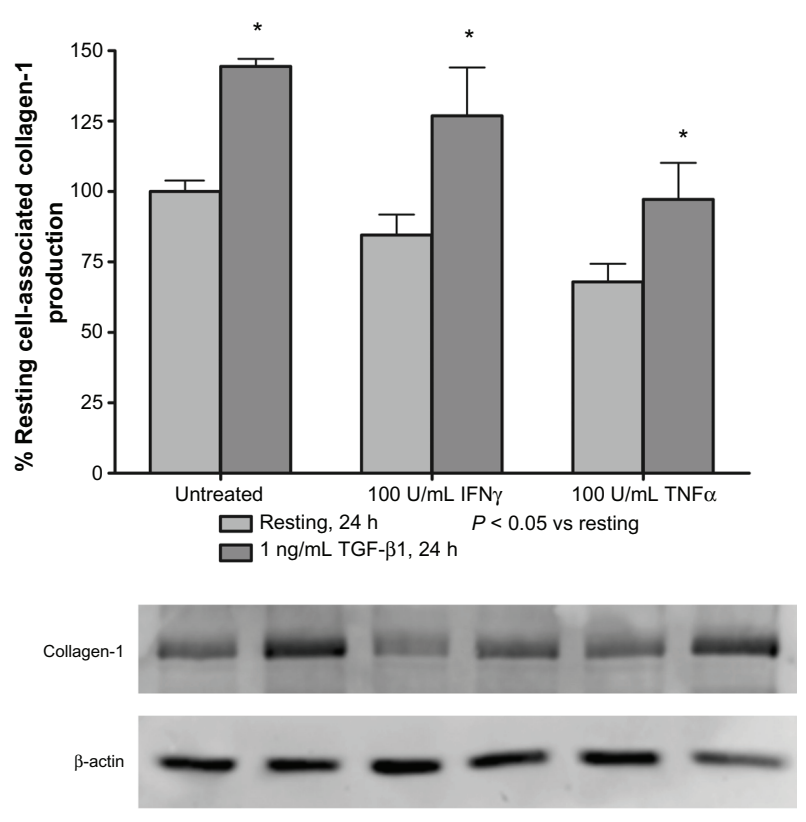

Figure I IFN $\gamma$ inhibits A2A receptor mediated collagen I production in LX-2 cells. LX-2 cells were cultured overnight in the presence or absence of IFN $\gamma$ and TNF $\alpha$ and treated with the A2AR agonist CGS2I680 (A) or TGF- $\beta$ I (B) for 24 hours as described in the Materials and methods section. Cellular collagen-I content was determined by densitometric measurements of immunoblots of whole cell lysates and normalized to $\beta$-actin content. A) CGS2 1680 increased collagen-I protein ( $21 \% \pm 5 \%$ increase relative to control, $P<0.05$, $n=7)$ compared with $100 \%$ baseline collagen-I production. This increase was enhanced in the presence of TNF $\alpha(37 \% \pm 18 \%$ increase relative to control, $P<0.05, n=5)$ and inhibited in the presence of IFN $\gamma(8 \% \pm 4 \%$ decrease relative to control, $P=n$.s., $n=7)$. $P$-values are derived from 2 -way ANOVA with Bonferroni posttest performed as post-hoc analysis. All instances of statistical significance $(P<0.05)$ are displayed in the figure. B) TGF- $\beta I$ increased collagen-I production $(44 \% \pm 3 \%$ increase relative to control, $P<0.05$, $\mathrm{n}=3$ ) by itself and in the presence of TNF $\alpha(45 \% \pm 21 \%$ increase relative to control, $P<0.05, \mathrm{n}=5)$ and IFN $\gamma(52 \% \pm 22 \%$ increase relative to control, $P<0.05, \mathrm{n}=3)$. $P$-values are derived from 2-way ANOVA with Bonferroni posttest performed as post-hoc analysis. All instances of statistical significance $(P<0.05)$ are displayed in the figure. Abbreviations: IFN $\gamma$, interferon-gamma; TNF $\alpha$, tumor necrosis factor alpha; A2AR, adenosine A2A receptor; TGF- $\beta$ I, tumor growth factor beta I. 
A

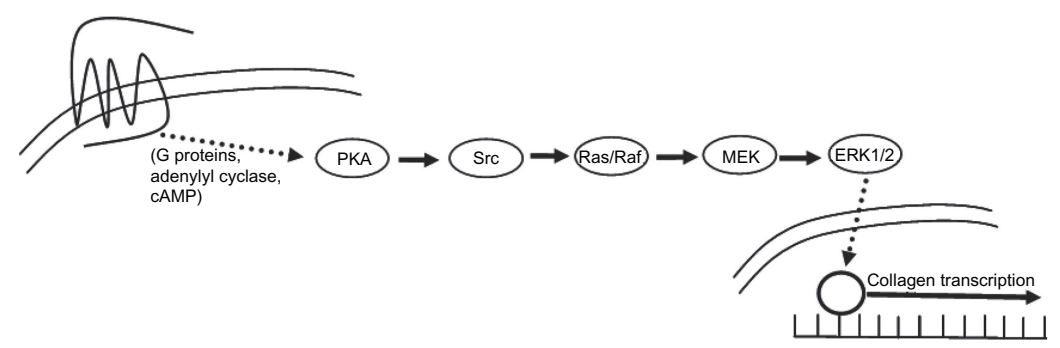

B
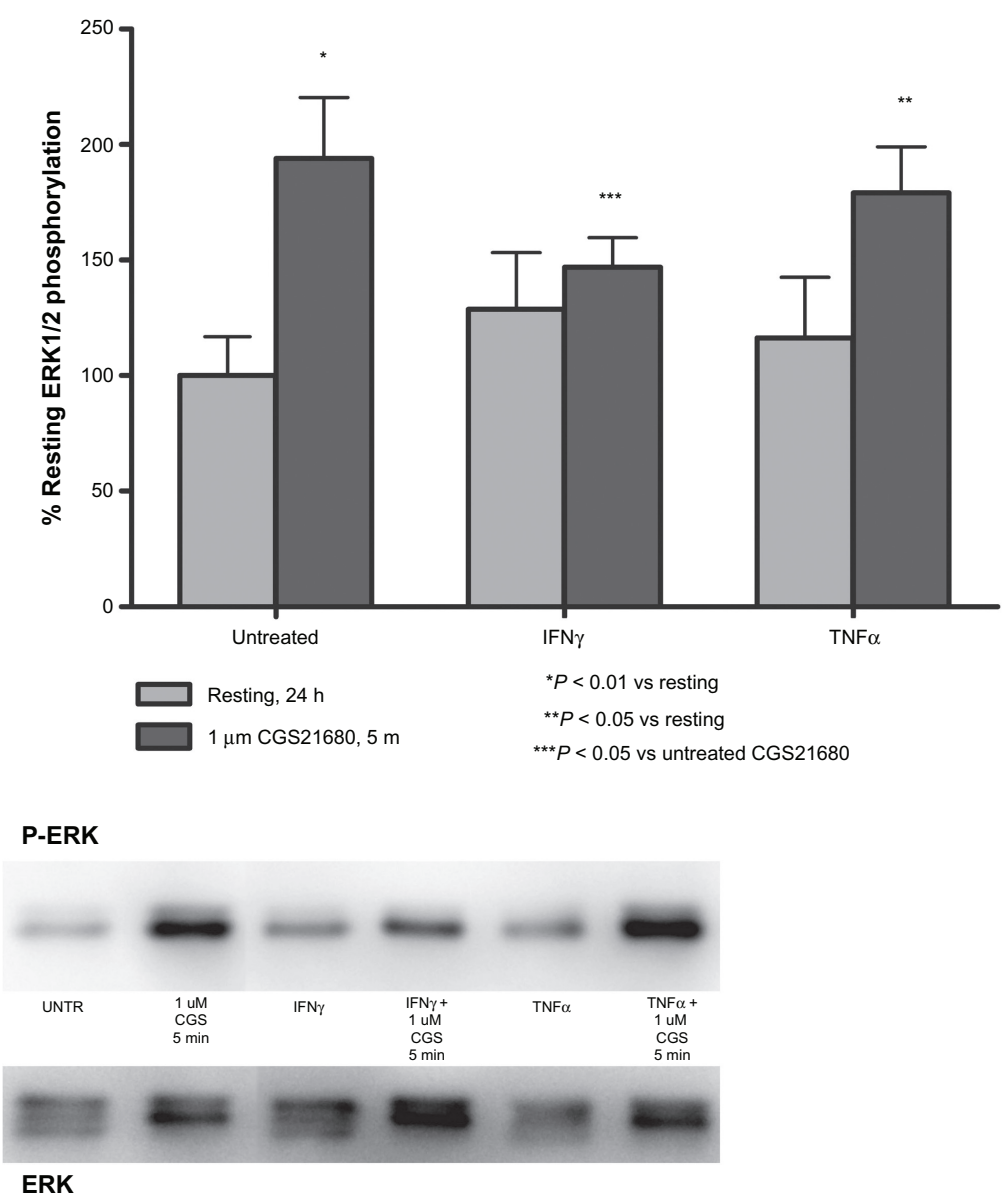

Figure 2 IFN $\gamma$ impairs the ability of an A2A receptor specific agonist to induce ERK phosphorylation in LX-2 cells. A) A schematic representation of the A2A receptor signaling pathway in LX-2 cells. B) LX-2 cells were cultured overnight in the presence or absence of IFN $\gamma$ and TNF $\alpha$ and treated with the A2AR agonist CGS2I680 for 5 minutes as described in the Materials and methods section. Phospho-ERK content was determined by densitometric measurements of immunoblots of whole cell lysates and normalized to total ERK content. CGS2I 680 increased ERKI/2 phosphorylation $(94 \% \pm 26 \%$ increase relative to control, $P<0.01, n=6)$ by itself and in the presence of $\mathrm{TNF} \alpha(70 \% \pm 36 \%$ increase relative to control, $P<0.05, \mathrm{n}=3)$ compared with baseline ERKI/2 phosphorylation. This increase was inhibited in the presence of IFN $\gamma(30 \% \pm$ $20 \%$ increase relative to control, $P=$ n.s. vs control and $P<0.05$ vs untreated CGS2 I680, $n=6$ ). $P$-values are derived from 2-way ANOVA with Bonferroni posttest performed as post-hoc analysis. All instances of statistical significance $(P<0.05)$ are displayed in the figure.

Abbreviations: IFN $\gamma$, interferon-gamma; TNF $\alpha$, tumor necrosis factor alpha; cAMP, cyclic AMP; PKA, protein kinase A; ERKI/2, extracellular signal-related protein kinases I and 2; A2AR, adenosine A2A receptor.

coupled receptor signaling leads to protein kinase A (PKA) activation and phosphorylation of extracellular signal-related protein kinases 1 and 2 (ERK1/2), which is required for A2A receptor mediated collagen-1 production. To determine if A2A receptor signal transduction is inhibited by IFN $\gamma$, we measured the ability of the A2A receptor specific agonist CGS21680 to induce ERK1/2 phosphorylation in the presence and absence of cytokines. As expected, CGS21680 increased ERK1/2 phosphorylation $(94 \% \pm 26 \%$ increase relative to control, $P<0.01$, $\mathrm{n}=6$ ). This 2 -fold increase was transient and peaked 5 minutes after CGS21680 addition. CGS21680-stimulated increases on ERK1/2 phosphorylation were unaffected by the presence 
of TNF $\alpha(70 \% \pm 36 \%$ increase relative to control, $P<0.05$, $\mathrm{n}=3$ ). In contrast, IFN $\gamma$ impaired the ability of CGS 21680 to increase ERK1/2 phosphorylation $(30 \% \pm 20 \%$ increase relative to control, $P=$ n.s. vs $100 \%$ control and $P<0.05$ vs CGS21680 no cytokine, $\mathrm{n}=6$ ) (Figure $2 \mathrm{~B}$ ). These results indicate that IFN $\gamma$ inhibits $\mathrm{A} 2 \mathrm{~A}$ receptor signal transduction upstream of ERK1/2 phosphorylation IFN $\gamma$.

\section{IFN $\gamma$ impairs the ability of CGS2I680 to induce cAMP formation in hepatic stellate cells}

cAMP is required for activation of PKA and is located upstream of ERK1/2 in the A2A receptor signal transduction pathway. We have previously demonstrated that IFN $\gamma$ inhibits A2A receptor-mediated cAMP production in THP-1 cells. In LX-2 cells, CGS21680 increased intracellular cAMP levels in a time-dependent manner, with a peak at 5 minutes after stimulation $(48 \% \pm 20 \%$ increase relative to control, $\mathrm{n}=15$ ). Increased cAMP levels were sustained for at least 20 minutes. IFN $\gamma$ inhibited A2A receptor-stimulated cAMP production increase $(5 \% \pm 21 \%$ increase relative to control, $P<0.05$ vs CGS21680 alone, $\mathrm{n}=11$ ) (Figure 3 ).

\section{IFN $\gamma$ regulates the expression of adenylyl cyclase message in an isoform specific manner}

Kolachala et al have demonstrated that IFN $\gamma$ inhibits adenosine $\mathrm{A} 2 \mathrm{~B}$ receptor function in human intestinal epithelial cells by downregulating expression of specific isoforms of adenylyl cyclase. ${ }^{20}$ We used realtime RT-PCR to examine expression of all 9 isoforms of adenylyl cyclase in LX-2 cells. mRNA encoding adenylyl cyclase isoform 1 (AC1), normally associated with neuronal cells, was not expressed in LX-2 cells, and message for isoforms AC2, AC4, and AC8 was expressed at very low levels. The message for the remaining 5 adenylyl cyclase isoforms was expressed at much higher levels (data not shown). We measured the effect of IFN $\gamma$ on adenylyl cyclase mRNA levels for the 5 highly expressed isoforms. mRNA levels for AC6 and AC7 did not change upon IFN $\gamma$ treatment. mRNA levels for AC5 exhibited a transient increase over time upon IFN $\gamma$ treatment. mRNA levels for AC3 $(0.73 \pm 0.13)$ and AC9 $(0.80 \pm 0.90)$ were significantly decreased $(P<0.05, \mathrm{n}=6) 24$ hours after IFN $\gamma$ treatment (Figure 4). We conclude that IFN $\gamma$ downregulates expression of AC3 and AC9.

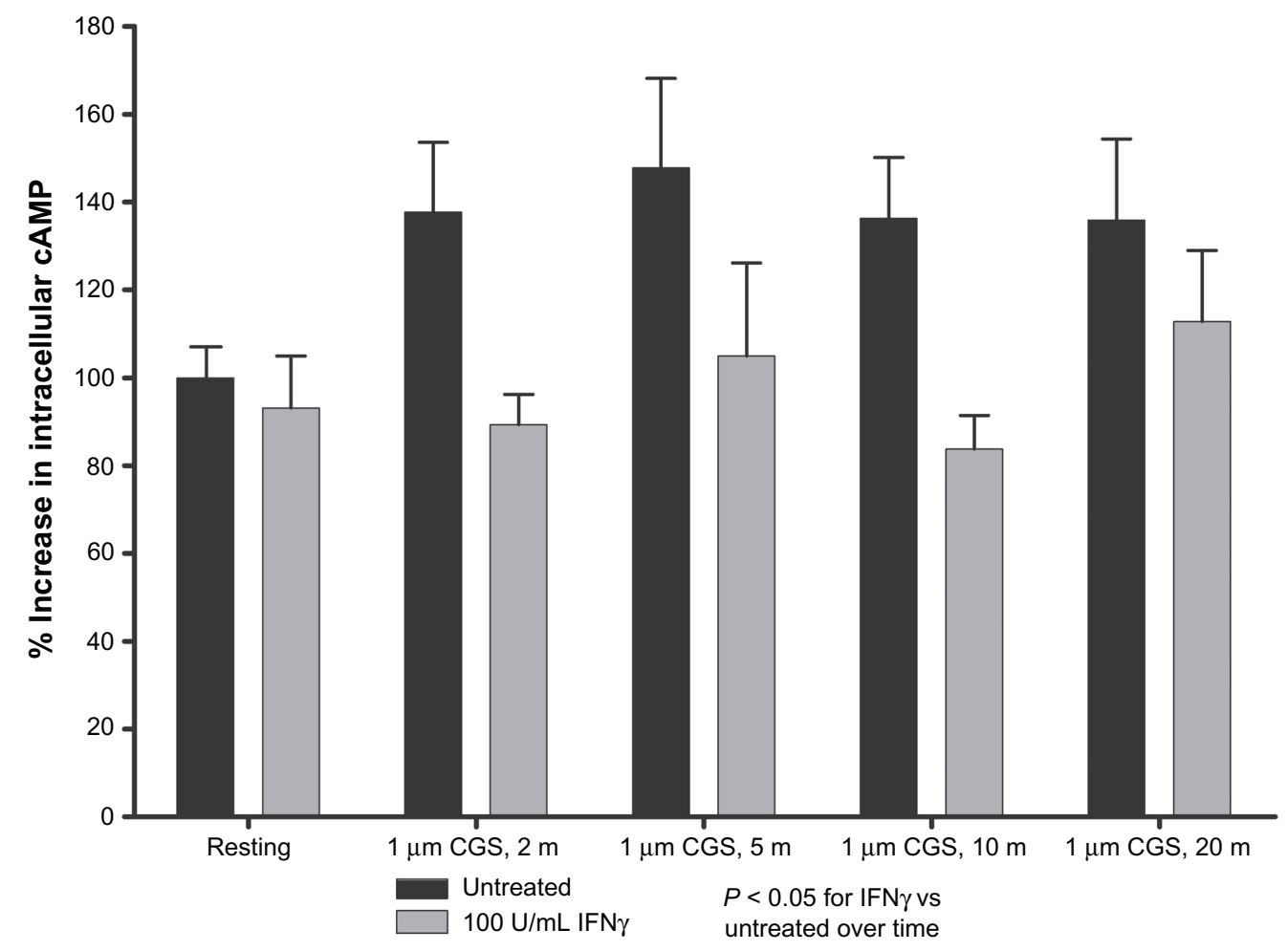

Figure 3 IFN $\gamma$ impairs the ability of an A2A receptor specific agonist to induce cAMP production in LX-2 cells. LX-2 cells were cultured overnight in the presence or absence of IFN $\gamma$ and TNF $\alpha$ and treated with the A2AR agonist CGS21680 as described in the Materials and methods section. Intracellular cAMP content was determined by ELISA and normalized to cytosolic protein levels. Basal cAMP levels were $34 \mathrm{pmol} / \mathrm{mg}$ intracellular protein. 5 minutes treatment with CGS2I680 increased intracellular cAMP levels $(48 \% \pm 20 \%$ increase relative to control, $\mathrm{n}=15)$ and IFN $\gamma$ inhibited this increase $(5 \% \pm 21 \%$ increase relative to control, $P<0.05, \mathrm{n}=1 \mathrm{I})$. $P$-values are derived from 2 -way ANOVA comparing treatments over time. Post-hoc analysis using Bonferroni posttest does not identify statistical significance between any 2 individual points. Abbreviations: IFN $\gamma$, interferon-gamma; A2AR, adenosine A2A receptor; TNF $\alpha$, tumor necrosis factor alpha; cAMP, cyclic AMP. 


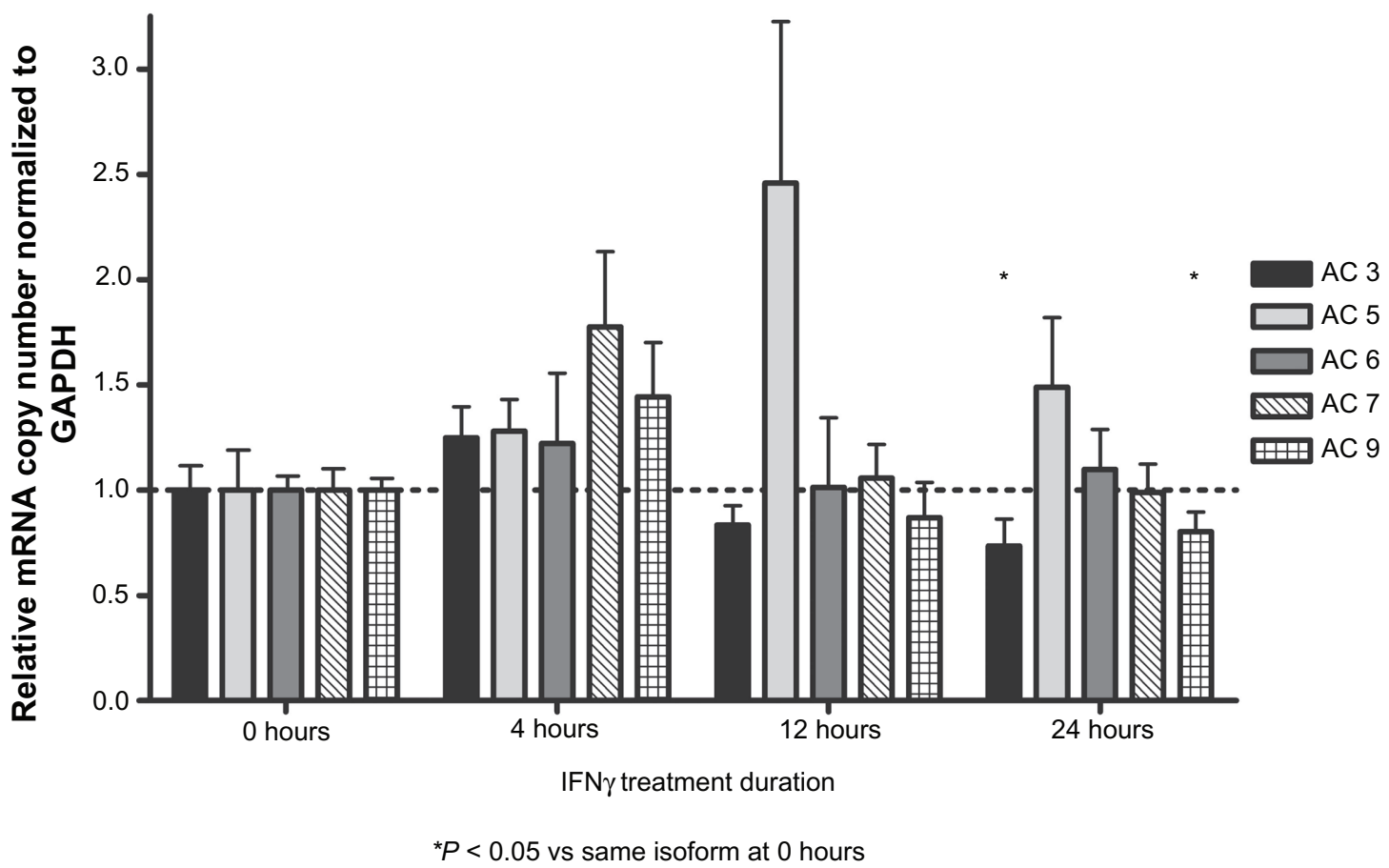

Figure 4 IFN $\gamma$ downregulates expression of adenylyl cyclase isoforms 3 and 9 in LX-2 cells. Adenylyl cyclase mRNA levels were determined by realtime RT-PCR of whole cell RNA preparations and normalized to GAPDH mRNA levels. LX-2 cells were treated with IFN $\gamma\left(100 \mathrm{UmL}^{-1}\right)$, and adenylyl cyclase mRNA levels were determined using $\mathrm{C}(\mathrm{t})$ values. 24 hours after IFN $\gamma$ treatment, mRNA levels for isoforms $3(0.73 \pm 0.13)$ and $9(80 \pm 0.09)$ were significantly decreased $(P<0.05, \mathrm{n}=6)$ relative to basal levels. mRNA copy numbers were approximately I adenylyl cyclase per $1000 \mathrm{GAPDH}$. P-values are derived from $t$-tests comparing timepoints for a given treatment.

Abbreviations: IFN $\gamma$, interferon-gamma; GAPDH, glyceraldehyde 3-phosphate dehydrogenase.

IFN $\gamma$ has no effect on the ability of forskolin, a small molecule activator of adenylyl cyclase, to induce cAMP production in LX-2 cells (data not shown). This suggests that AC9 rather than $\mathrm{AC} 3$ is required for A2A receptor signaling and function. AC9 is uniquely insensitive to forskolin activation. ${ }^{22}$ Our observation that forsoklin is unable to increase collagen-1 production in LX-2 cells supports a requirement for AC9 (data not shown). The inability of forskolin to increase collagen expression in fibroblasts is well established. ${ }^{32,33}$

\section{Downregulation of adenylyl cyclase expression impairs A2A receptor signaling and function}

We hypothesized that $\mathrm{AC} 3$ or AC9 is required for $\mathrm{A} 2 \mathrm{~A}$ receptor function. We used siRNA to reduce expression of these 2 isoforms as seen in the Materials and methods section. siRNA knockdown of AC3 decreased AC3 expression $(0.40 \pm 0.06, \mathrm{n}=3)$ but not AC9 expression (1.72 \pm 0.13 , $\mathrm{n}=2$ ). siRNA knockdown of AC9 decreased AC9 expression $(0.59 \pm 0.02, \mathrm{n}=3)$ but not AC3 expression (1.44 \pm 0.17 , $\mathrm{n}=2$ ) (Figure $5 \mathrm{~A}$ ). We then examined $\mathrm{A} 2 \mathrm{~A}$ receptor function in these cells. We determined the ability of siRNA to impair CGS21680 induced adenylyl cyclase activity by measuring
cAMP concentration. As seen previously, the A2A receptor specific agonist CGS21680 increased intracellular cAMP levels in a time-dependent manner, with a peak at 5 minutes after stimulation $(116 \% \pm 46 \%$ increase relative to control, $\mathrm{n}=4)$. The knockdown of either AC3 (13\% $\pm 19 \%$ increase relative to control, $P<0.05$ vs CGS21680 alone, $\mathrm{n}=4$ ) or AC9 $(20 \% \pm 19 \%$ increase relative to control, $P<0.05$ vs CGS21680 alone, $\mathrm{n}=4$ ) blocked CGS21680 induced intracellular cAMP production (Figure 5B). Similarly, knockdown of either AC3 $(6 \% \pm 3 \%$ decrease, $n=5)$ or AC9 $(7 \% \pm 1 \%$ decrease, $\mathrm{n}=5)$ abrogated CGS21680-mediated collagen-1 protein production in a statistically significant manner $(P<0.05)$ (Figure 5C). Thus, the knockdown of either AC3 or AC9 prevents signaling at A2ARs necessary for increased collagen production.

\section{IFN $\gamma$ regulates $A 2 A$ receptor function in a STATI dependent manner}

Canonical IFN $\gamma$ signal transduction is mediated by signal transducers and activators of transcription (STATs), a family of 7 transcription factors. ${ }^{23,24}$ To determine whether STATs mediate IFN $\gamma$ regulation of A2A receptor function, we used siRNA to knock down STAT1 and STAT3 as seen in the Materials and methods section (Figure 6A). Both STAT1 and 
A

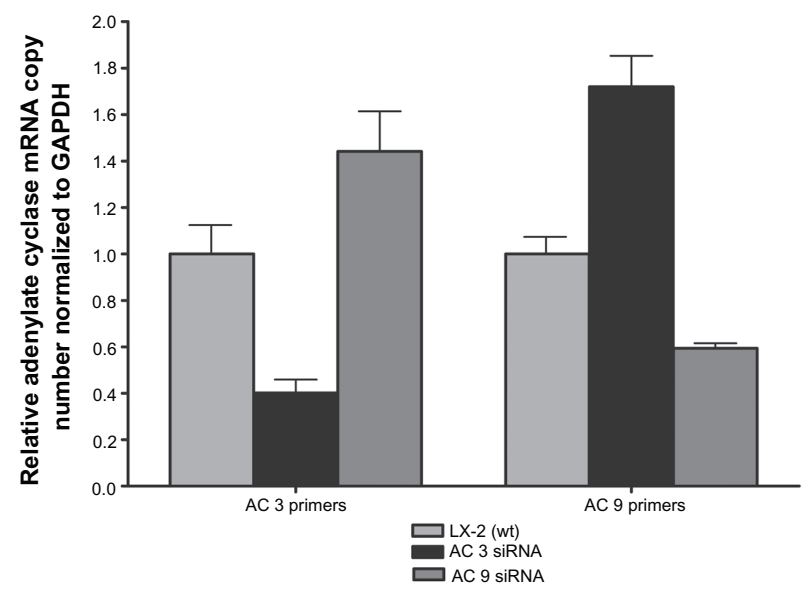

C

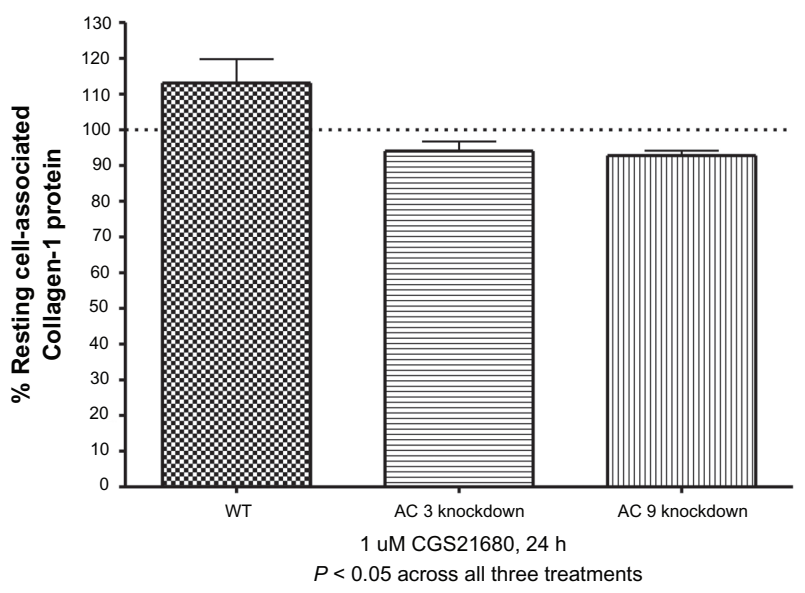

B
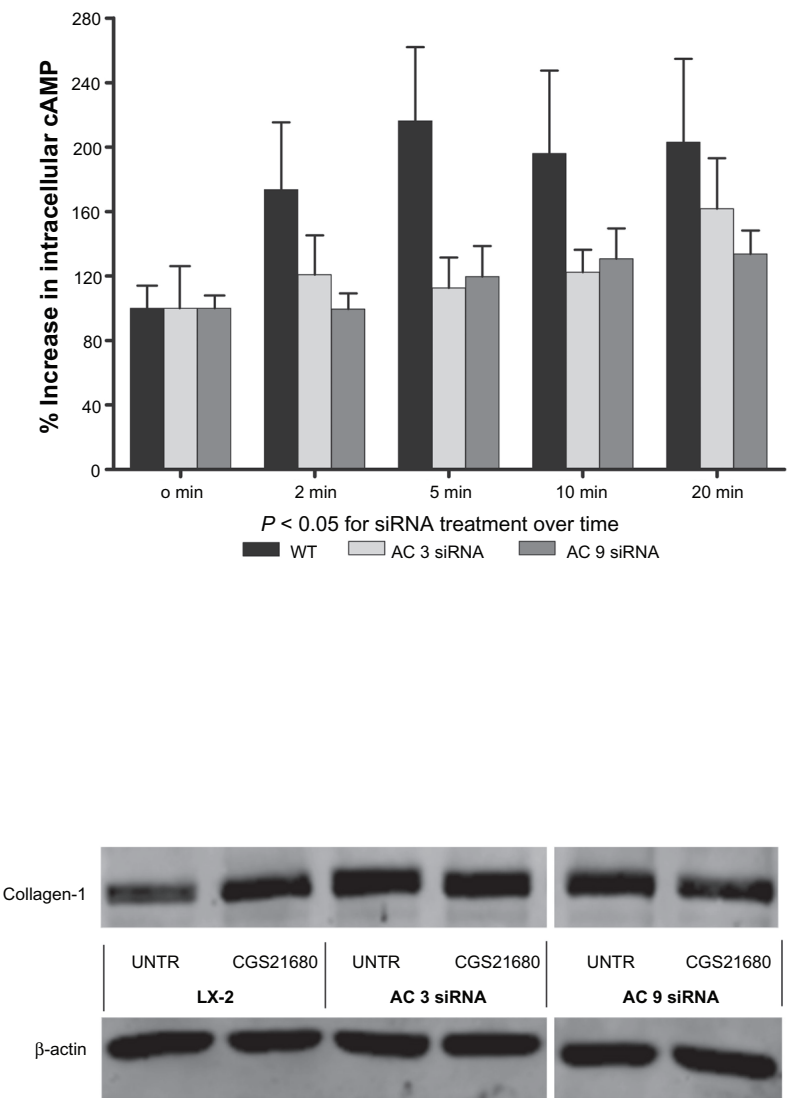

Figure 5 Downregulation of either adenylyl cyclase isoform 3, 6, or 9 inhibits A2A receptor signaling and function in LX-2 cells. Lentiviruses containing siRNA constructs were used to create three separate cell lines, each with impaired expression of a different adenylyl cyclase isoform. A) Cellular adenylyl cyclase mRNA content was determined by realtime QPCR and normalized to GAPDH levels. siRNA knockdown of AC3 decreased AC3 expression ( $0.40 \pm 0.06, \mathrm{n}=3)$ but not AC9 expression (I.72 $\pm 0.13, n=2)$ relative to basal levels. siRNA knockdown of AC9 decreased AC9 expression $(0.59 \pm 0.02, n=3)$ but not $A C 3$ expression $(1.44 \pm 0.17$, $n=2)$ relative to basal levels. mRNA copy numbers were approximately I adenylyl cyclase per I000 GAPDH. B) A2ARs were activated by incubation with the specific agonist CGS2 I680 (I $\mu$ M). Intracellular cAMP content was determined by ELISA and normalized to cytosolic protein levels. Basal cAMP levels were 42 pmol/mg intracellular protein. The 5 minute treatment with CGS2I680 increased intracellular cAMP (II6\% $\pm 46 \%$ increase relative to control, $n=4)$. Knockdown of AC3 (I3\% $\pm 19 \%$ increase relative to control, $P<0.05, \mathrm{n}=4)$ or AC9 $(20 \% \pm 19 \%$ increase relative to control, $P<0.05, \mathrm{n}=4)$ inhibited CGS2I 680 increased intracellular cAMP. $P$-values are derived from 2 -way ANOVA for treatment groups over time. Post-hoc analysis using Bonferroni posttest does not identify statistical significance between any 2 individual points. C) A2ARs were activated by incubation with the specific agonist CGS2I680 (I $\mu \mathrm{M})$ for 24 hours. CGS2 I680 increased collagen-I protein expression $(13 \% \pm 7 \%, \mathrm{n}=5)$. Knockdown of AC3 ( $6 \% \pm 3 \%$, $n=5)$ or AC9 $(-7 \% \pm 1 \%, n=5)$ inhibited CGS2 1680 induced collagen-I protein expression in a statistically significant manner $(P<0.05)$. $P$-values are derived from 2 -way ANOVA with Bonferroni posttest performed as post-hoc analysis. All instances of statistical significance $(P<0.05)$ are displayed in the figure.

Abbreviations: GAPDH, glyceraldehyde 3-phosphate dehydrogenase; A2AR, adenosine A2A receptor; cAMP, cyclic AMP.

STAT3 are phosphorylated by IFN $\gamma$ in LX-2 cells, while the other isoforms are unaffected (data not shown). We previously demonstrated that ERK1/2 phosphorylation is required for A2A receptor mediated collagen-1 production. ${ }^{18}$ We measured A2A receptor mediated ERK1/2 phosphorylation in STAT knockdown cells in the presence and absence of IFN $\gamma$.

CGS21680 increased ERK phosphorylation (32\% $\pm 8 \%$ increase relative to control, $P<0.05, \mathrm{n}=3$ ) and the presence of IFN $\gamma$ again prevented A2A receptor mediated ERK phosphorylation $(13 \% \pm 5 \%$ increase relative to control, $P=$ n.s., $\mathrm{n}=3$ ). In LX-2 cells with impaired STAT3 expression, CGS21680 increased ERK phosphorylation to levels similar to wild type cells $(44 \% \pm 19 \%$ increase relative to control, $P<0.01, \mathrm{n}=3$ ) and the presence of IFN $\gamma$ prevented A2A receptor mediated ERK phosphorylation $(19 \% \pm 18 \%$ increase relative to control, $P>0.05, \mathrm{n}=3)$. In LX-2 cells with impaired STAT1 expression, CGS21680 increased ERK phosphorylation similar to wild type cells ( $46 \% \pm 20 \%$ increase relative to control, $P<0.01, \mathrm{n}=3$ ), but STAT1 knockdown abrogated IFN $\gamma$ mediated inhibition of A2A receptor mediated ERK phosphorylation $(44 \% \pm 20 \%$ increase relative to control, $P<0.01, \mathrm{n}=3)$ 
A

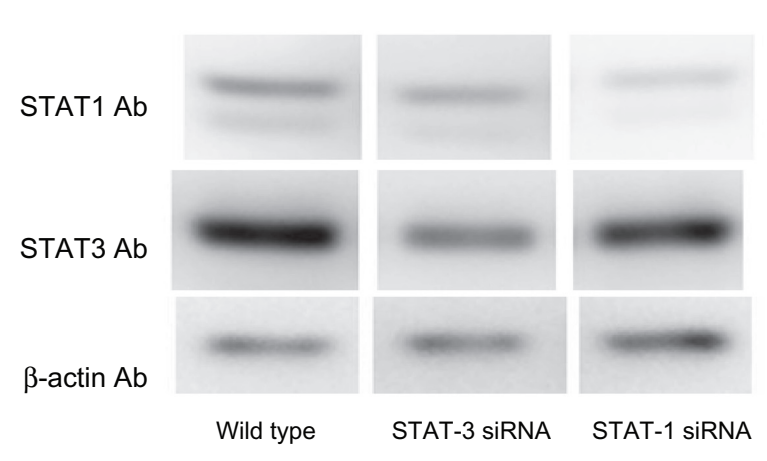

C

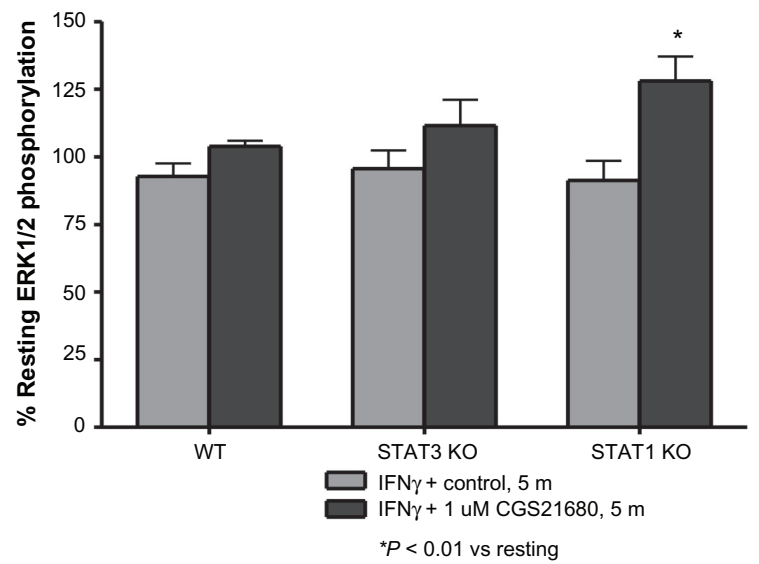

B

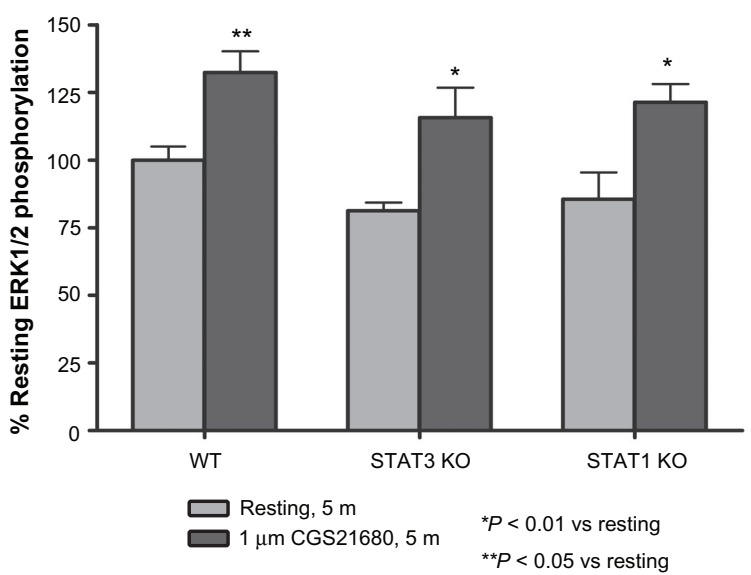

P-Erk

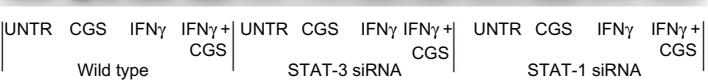

Erk

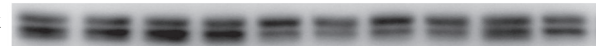

Figure 6 IFN $\gamma$ has no effect on the ability of CGS2I 680 to induce ERK phosphorylation in LX-2 cells with impaired STATI expression. A) STATI and STAT3 content was determined by immunoblots of whole cell lysates normalized to $\beta$-actin content. siRNA knockdown of STAT3 decreased STAT3 expression but not STATI expression. siRNA knockdown of STATI decreased STATI expression but not STAT3 expression. All pictures are from the same gel, which was stripped and reprobed. B, C) LX-2 cells were cultured overnight in the presence or absence of IFN $\gamma$ and TNF $\alpha$ and treated with the A2AR agonist CGS2I680 for 5 minutes as described in the Materials and methods section. Phospho-ERK content was determined by densitometric measurements of immunoblots of whole cell lysates and normalized to total ERK content. CGS2I 680 increased ERK phosphorylation in wild-type cells $(32 \% \pm 8 \%$ increase relative to control, $P<0.05, \mathrm{n}=3$ ) was unaffected by knockdown of STAT3 (44\% $\pm 19 \%$ increase relative to control, $P<0.0 \mathrm{I}, \mathrm{n}=3)$ and STATI $(46 \% \pm 20 \%$ increase relative to control, $P<0.0 \mathrm{I}, \mathrm{n}=3)$. IFN $\gamma$ inhibited CGS2I680 increased ERK phosphorylation in wild-type cells $(13 \% \pm 5 \%$ increase relative to control, $P=$ n.s., $n=3)$ and STAT3 knockdown cells $(19 \% \pm 18 \%$ increase relative to control, $P<0.05$, $n=3)$. Knockdown of STATI abrogated inhibition $(44 \% \pm 20 \%$ increase relative to control, $P<0.01, n=3)$. $P$-values are derived from 2 -way ANOVA with Bonferroni posttest performed as post-hoc analysis.

Abbreviations: IFN $\gamma$, interferon-gamma; STATI, signal transducer and activator of transcription I; TNF $\alpha$, tumor necrosis factor alpha; ERKI/2, extracellular signal-related protein kinases I and 2; A2AR, adenosine A2A receptor; STAT3, signal transducer and activator of transcription 3.

(Figures 6B and 6C). We conclude that STAT1 expression is necessary for IFN $\gamma$ mediated regulation of $\mathrm{A} 2 \mathrm{~A}$ receptor function. The inability of either siRNA to affect A2A receptor signal transduction controls for non-specific siRNA effects on A2A receptor signaling and function.

\section{Discussion}

We report here that IFN $\gamma$ inhibits the ability of the A2A receptor specific agonist CGS21680 to induce collagen production, ERK phosphorylation, and cAMP production in LX-2 cells. IFN $\gamma$ impairs adenylyl cyclase expression, and adenylyl cyclase transduces the A2A receptor signal for increased collagen production. Moreover, we have found that the JAK/STAT pathway mediates the effect of IFN $\gamma$ on $\mathrm{A} 2 \mathrm{~A}$ receptor function. We conclude that IFN $\gamma$ inhibits the function of the A2AR by downregulating the expression of AC3 and AC9 in a STAT1 mediated fashion (Figure 7). While both IFN $\gamma$ and TNF $\alpha$ decrease basal collagen-1 protein levels in LX-2 cells, they have opposite effects on hepatic fibrosis in vivo. Increased TNF $\alpha$ levels are associated with increased hepatic fibrosis in human and animal models. ${ }^{21}$ This suggests that the clinically relevant effect of IFN $\gamma$ on hepatic fibrosis is one it does not share with TNF $\alpha$, such as an ability to inhibit A2A receptor function. In vivo protection from hepatic fibrosis afforded by IFN $\gamma$ may therefore be due, at least in part, to inhibition of A2A receptor mediated collagen production. 


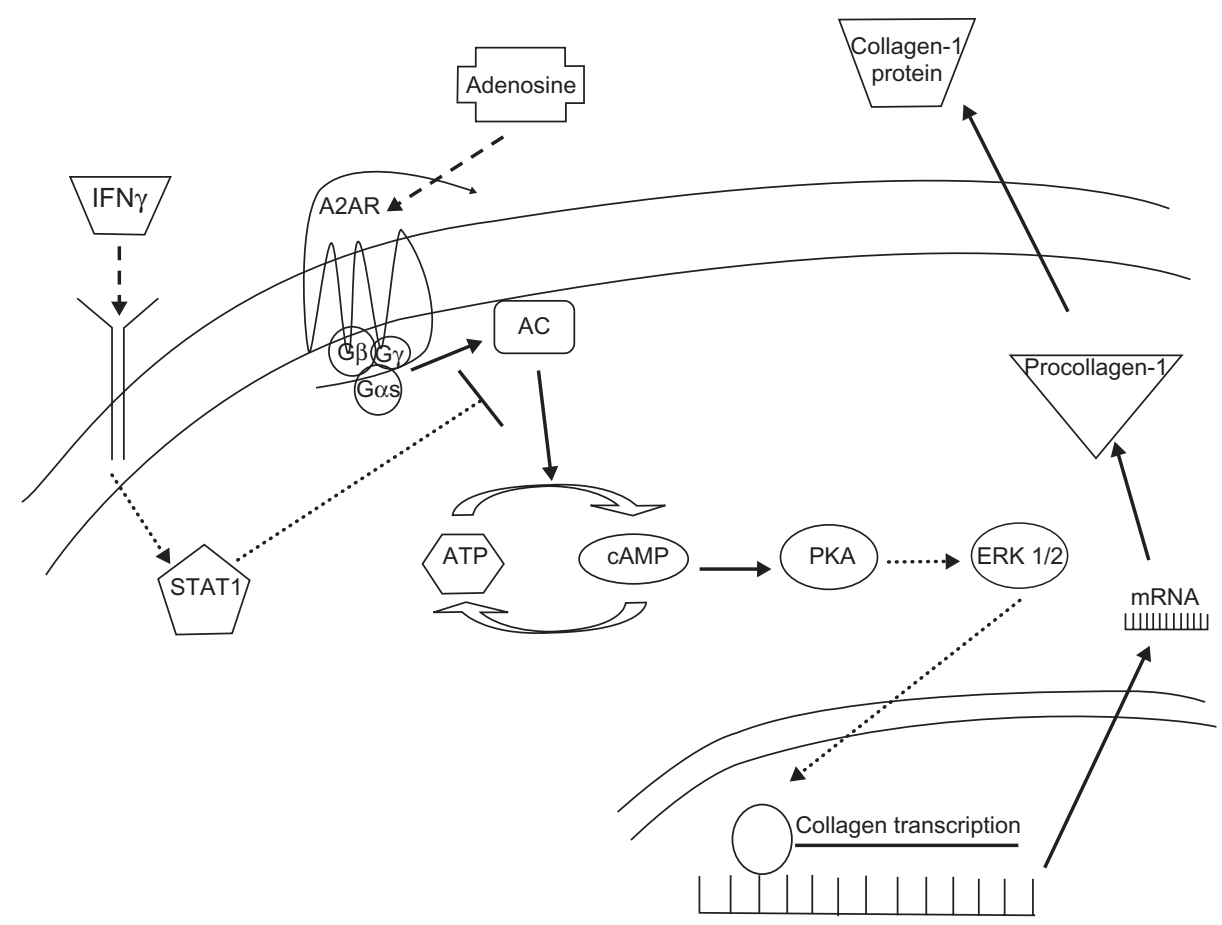

Figure 7 Proposed model for the mechanism by which IFN $\gamma$ impairs A2A receptor signaling and function.

Abbreviations: IFN $\gamma$, interferon-gamma; A2AR, adenosine A2A receptor; STATI, signal transducer and activator of transcription I; cAMP, cyclic AMP; PKA, protein kinase $A$; ERKI/2, extracellular signal-related protein kinases $I$ and 2.

Our data suggest a role for multiple adenylyl cyclase isoforms in A2A receptor signaling. Cooper and Crossthwaite summarize recent evidence demonstrating that oligomerization is a key feature in adenylyl cyclase function. Increases in cAMP levels are tightly localized to membrane microdomains whose organization is determined by the ability of molecules including adenylyl cyclase to form higher-order structures. ${ }^{25}$ Oligomerization is necessary to recruit adenylyl cyclase to multimeric signaling assemblies required for efficient GPCR signal transduction. ${ }^{26}$ We speculate that AC3 and $\mathrm{AC} 9$ oligomerization is required for $\mathrm{A} 2 \mathrm{~A}$ receptor signal transduction. Both isoforms may be necessary to localize adenylyl cyclase to the A2A signaling module. AC3 and $\mathrm{A} 2 \mathrm{~A}$ are observed in membrane microdomains, while AC9 is not. Alternatively, oligomerization may increase adenylyl cyclase activity to levels needed to achieve sufficiently high levels of cAMP for downstream signaling. Adenylyl cyclase oligomerization in the presence of Gos was demonstrated to enhance enzymatic function. ${ }^{27}$ To the best of our knowledge, this is the first suggestion that these two particular adenylyl cyclase isoforms may oligomerize in vivo.

Further study examining the localization of the molecules involved in A2A receptor signal transduction is warranted. We are particularly interested in the co-localization of AC3 and AC9, as well as changes in localization of both isoforms upon
AC3 and AC9 knockdown. Knockdown of adenylyl cyclase may also disrupt the function of other A2A receptor signaling mediators. Expression of different GPCR signaling molecules are all linked. For example, siRNA mediated knockdown of G $\beta$ protein alters $G \alpha$ and adenylyl cyclase protein expression. ${ }^{22}$ Adenylyl cyclase isoforms also cross-regulate each other. For example, AC6 can regulate $\mathrm{Ca}^{2+}$ influx and $\mathrm{Ca}^{2+}$ influx $\mathrm{AC} 1$, $\mathrm{AC} 3$, and $\mathrm{AC} 8$ while inhibiting AC5 and AC6. ${ }^{25,28}$

It remains possible that IFN $\gamma$ regulates adenylyl cyclase activity in addition to expression. Adenylyl cyclase activity is regulated post-transcriptionally by molecules such as regulator of $\mathrm{G}$ protein signaling (RGS), PKA, PKC, and calmodulin kinase, which may be affected by IFN $\gamma$ treatment. ${ }^{22}$ IFN $\gamma$ could also increase the activity or expression of phosphodiesterases (PDEs). PDEs regulate adenylyl cyclase function by catalyzing the hydrolysis of cAMP into AMP. ${ }^{29,30}$ Increased PDE activity would inhibit $\mathrm{A} 2 \mathrm{~A}$ receptor signaling by preventing cAMP from activation PKA and Epac. PDEs are unlikely to mediate the effect of IFN $\gamma$ on A2A receptor function, however, since IFN $\gamma$ was shown to downregulate expression of multiple PDEs, as well as RGS2, in pancreatic stellate cells. ${ }^{31}$ Decreased expression of regulatory molecules such as PDEs would increase $\mathrm{A} 2 \mathrm{~A}$ function rather than inhibit it.

Previous studies in our lab have demonstrated the ability of IFN $\gamma$ to regulate A2A receptor function in THP-1 human 
monocyte cell line. ${ }^{13}$ It remains to be determined whether IFN $\gamma$ also downregulates adenylyl cyclase expression in these cells. It is interesting that while IFN $\gamma$ has an opposite effect from TNF $\alpha$ on A2A receptor function in THP-1 cells, it has a completely different mechanism of action. Previous research in our laboratory has demonstrated that TNF $\alpha$ enhances A2A receptor activity by impairing GRK2 and $\beta$-arrestin mediated receptor desensitization in the THP-1 human monocyte cell line. ${ }^{14}$ Treatment with CGS21680 increased membrane bound GRK2 in LX-2 cells, but the presence of IFN $\gamma$ had no effect on CGS21680 induced GRK2 translocation (data not shown). Consistent with observations in THP-1 cells, TNF $\alpha$ blocked A2A receptor-mediated GRK2 translocation to the cell membrane (data not shown). Unlike TNF $\alpha$, IFN $\gamma$ has no effect on GRK2 translocation and A2A receptor desensitization. While TNF $\alpha$ impairs A2A receptor desensitization, IFN $\gamma$ has no effect on desensitization, but directly impairs the $\mathrm{A} 2 \mathrm{~A}$ receptor signal transduction cascade.

We have shown that the effect of IFN $\gamma$ on A2A receptor function is mediated by STAT1, but it remains unclear whether or not STAT1 directly suppresses adenylyl cyclase expression. Sequence analysis of adenylyl cyclase promoter regions failed to identify a consensus binding site for STAT1, supporting the hypothesis that STAT1 regulates another transcription factor with the ability to regulate adenylyl cyclase expression. Further analysis is necessary to determine putative regulatory factor binding sites in the adenylyl cyclase promoter region in order to identify this unknown intermediary.

Studies in patients with hepatitis $\mathrm{B}^{32}$ and rats with CCl4- induced hepatic fibrosis ${ }^{33,34}$ have shown that IFN $\gamma$ exerts a protective effect on liver fibrosis in vivo, but have not considered a potential role for the adenosine receptor. ${ }^{32,35}$ IFN $\gamma$ prevents activation of hepatic stellate cells both in vitro ${ }^{36}$ and in vivo. ${ }^{37}$ However, our results demonstrate a novel role for IFN $\gamma$ in regulating hepatic stellate cell activity post- activation. This may prove clinically relevant, as the components of the adenosine receptor signaling pathway provide new targets for drug development to treat hepatic fibrosis. ${ }^{38}$ Furthermore, a role for adenosine receptors in fibrosis is not limited to the liver. Our lab has demonstrated a role for the $\mathrm{A} 2 \mathrm{~A}$ receptor in skin fibrosis ${ }^{39}$ and other adenosine receptors are relevant to the progression of cardiac $^{40}$ and pulmonary fibrosis. ${ }^{7}$ It is important to explore the ability of IFN $\gamma$ to regulate adenosine receptor function in these other tissues. Activation of the IFN $\gamma$ receptor or its signaling pathway could be used to treat fibrosis in these tissues as well.
We have identified a novel mechanism for regulation of adenosine receptor function by IFN $\gamma$ in the context of hepatic fibrosis. Ultimately, our results identify adenylyl cyclase activity and expression as a key point of regulation for adenosine receptor function and a potentially valuable therapeutic target for disease models involving adenosine receptor signaling, such as hepatic fibrosis.

\section{Acknowledgments}

This work was supported by a grant from the Vilcek Foundation and grants from the NIH to Dr Cronstein (AR56672, AR54897, GM56268, AA13336, and AR41911). In addition this work was supported by the NYU GCRC (MOIRR96).

\section{Conflicts of interest Eric T Block, PhD}

None.

\section{Bruce N Cronstein, MD}

Intellectual property

- Patents on use of A2AR agonists to promote wound healing and use of $\mathrm{A} 2 \mathrm{~A}$ receptor antagonists to inhibit fibrosis.

- Patent on use of adenosine A1 receptor antagonists to treat osteoporosis and other diseases of bone.

- Patent on the use of adenosine A1 and A26 receptor antagonists to treat fatty liver.

- Patent on the use of A2AR agonists to prevent prosthesis loosening.

Consultant (within the past two years), all $<\$ 10,000$

- Cypress Bioscience, Inc.

- King Pharmaceutical (licensee of patents above)

- CanFite Biopharmaceuticals

- Bristol-Myers Squibb

- Celizome

- Tap Pharmaceuticals

- Prometheus Laboratories

- Regeneron (Westat, DSMB)

- Sepracor

- Amgen

- Endocyte

- Protalex

- Allos, Inc.

- Combinatorx

- Kyowa Hakka 
- Hoffman-LaRoche

- Savient

- Avidimer Therapeutics

\section{Stock}

CanFite Biopharmaceuticals received for membership in Scientific Advisory Board.

\section{Grants}

- King Pharmaceuticals

- NIH

- Vilcek Foundation

- Board Member: Vilcek Foundation

\section{References}

1. Hasko G, Kuhel DG, Chen JF, et al. Adenosine inhibits IL-12 and TNF-[alpha] production via adenosine A2a receptor-dependent and independent mechanisms. FASEB J. 2000;14:2065-2074.

2. Picher M, Burch LH, Hirsh AJ, Spychala J, Boucher RC. Ecto 5 '-nucleotidase and nonspecific alkaline phosphatase. two AMPhydrolyzing ectoenzymes with distinct roles in human airways. $J$ Biol Chem. 2003;278:13468-13479.

3. Thiel M, Caldwell CC, Sitkovsky MV. The critical role of adenosine $\mathrm{A} 2 \mathrm{~A}$ receptors in downregulation of inflammation and immunity in the pathogenesis of infectious diseases. Microbes Infect. 2003;5:515-526.

4. Ohta A, Sitkovsky M. Role of G-protein-coupled adenosine receptors in downregulation of inflammation and protection from tissue damage. Nature. 2001;414:916-920.

5. Reiss AB, Rahman MM, Chan ES, Montesinos MC, Awadallah NW, Cronstein BN. Adenosine A2A receptor occupancy stimulates expression of proteins involved in reverse cholesterol transport and inhibits foam cell formation in macrophages. J Leukoc Biol. 2004;76:727-734.

6. Montesinos MC, Desai A, Chen JF, et al. Adenosine promotes wound healing and mediates angiogenesis in response to tissue injury via occupancy of A(2A) receptors. Am J Pathol. 2002;160:2009-2018.

7. Chunn JL, Molina JG, Mi T, Xia Y, Kellems RE, Blackburn MR. Adenosine-dependent pulmonary fibrosis in adenosine deaminasedeficient mice. J Immunol. 2005;175:1937-1946.

8. Klinger M, Freissmuth M, Nanoff C. Adenosine receptors: $\mathrm{G}$ protein-mediated signalling and the role of accessory proteins. Cell Signal. 2002;14:99-108.

9. Jaakola VP, Griffith MT, Hanson MA, et al. The 2.6 angstrom crystal structure of a human A2A adenosine receptor bound to an antagonist Science. 2008;322:1211-1217.

10. Nguyen DK, Montesinos MC, Williams AJ, Kelly M, Cronstein BN. Th1 cytokines regulate adenosine receptors and their downstream signaling elements in human microvascular endothelial cells. J Immunol. 2003;171:3991-3998.

11. Wang L, Kolachala V, Walia B, et al. Agonist-induced polarized trafficking and surface expression of the adenosine $2 \mathrm{~b}$ receptor in intestinal epithelial cells: role of SNARE proteins. Am J Physiol Gastrointest Liver Physiol. 2004;287:G1100-G1107.

12. Willets JM, Parent JL, Benovic JL, Kelly E. Selective reduction in A2 adenosine receptor desensitization following antisense-induced suppression of G protein-coupled receptor kinase 2 expression. J Neurochem. 1999; 73:1781-1789.

13. Khoa ND, Montesinos MC, Reiss AB, Delano D, Awadallah N, Cronstein BN. Inflammatory cytokines regulate function and expression of adenosine $\mathrm{A}(2 \mathrm{~A})$ receptors in human monocytic THP-1 cells. J Immunol. 2001;167:4026-4032.
14. Khoa ND, Postow M, Danielsson J, Cronstein BN. Tumor necrosis factor-alpha prevents desensitization of Galphas-coupled receptors by regulating GRK2 association with the plasma membrane. Mol Pharmacol. 2006;69:1311-1319.

15. Chan ES, Montesinos MC, Fernandez P, et al. Adenosine A(2A) receptors play a role in the pathogenesis of hepatic cirrhosis. Br JPharmacol. 2006b;148:1144-1155.

16. Peng Z, Borea PA, Wilder T, et al. Adenosine signaling contributes to ethanol-induced fatty liver in mice. J Clin Invest. 2009;119:582-594.

17. Hashmi AZ, Hakim W, Kruglov EA, et al. Adenosine inhibits cytosolic calcium signals and chemotaxis in hepatic stellate cells. Am J Physiol Gastrointest Liver Physiol. 2007;292:G395-G401.

18. Che J, Chan ES, Cronstein BN. Adenosine A2A receptor occupancy stimulates collagen expression by hepatic stellate cells via pathways involving protein kinase A, src, and extracellular signal-regulated kinases $1 / 2$ signaling cascade or p38 mitogen-activated protein kinase signaling pathway. Mol Pharmacol. 2007;72:1626-1636.

19. Xu L, Hui AY, Albanis E, et al. Human hepatic stellate cell lines, LX-1 and LX-2: new tools for analysis of hepatic fibrosis. Gut. 2005;54: $142-151$.

20. Kolachala V, Asamoah V, Wang L, Srinivasan S, Merlin D, Sitaraman SV. Interferon-gamma down-regulates adenosine $2 \mathrm{~b}$ receptor-mediated signaling and short circuit current in the intestinal epithelia by inhibiting the expression of adenylate cyclase. J Biol Chem. 2005;280:4048-4057.

21. Knittel T, Muller L, Saile B, Ramadori G. Effect of tumour necrosis factor-alpha on proliferation, activation and protein synthesis of rat hepatic stellate cells. J Hepatol. 1997;27:1067-1080.

22. Willoughby D, Cooper DM. Organization and $\mathrm{Ca}^{2+}$ regulation of adenylyl cyclases in cAMP microdomains. Physiol Rev. 2007;87:965-1010.

23. Platanias LC. Mechanisms of type-I- and type-II-interferon-mediated signalling. Nat Rev Immunol. 2005;5:375-386.

24. Ramana CV, Gil MP, Schreiber RD, Stark GR. Stat1-dependent and -independent pathways in IFN-gamma-dependent signaling. Trends Immunol. 2002;23:96-101.

25. Cooper DM, Crossthwaite AJ. Higher-order organization and regulation of adenylyl cyclases. Trends Pharmacol Sci. 2006;27:426-431.

26. Gu C, Cali JJ, Cooper DM. Dimerization of mammalian adenylate cyclases. Eur J Biochem. 2002;269:413-421.

27. Baragli A, Grieco ML, Trieu P, Villeneuve LR, Hebert TE. Heterodimers of adenylyl cyclases 2 and 5 show enhanced functional responses in the presence of galpha s. Cell Signal. 2008;20:480-492.

28. Tovey SC, Dedos SG, Taylor EJ, Church JE, Taylor CW. Selective coupling of type 6 adenylyl cyclase with type 2 IP3 receptors mediates direct sensitization of IP3 receptors by cAMP. J Cell Biol. 2008;183:297-311.

29. Liu X, Ostrom RS, Insel PA. cAMP-elevating agents and adenylyl cyclase overexpression promote an antifibrotic phenotype in pulmonary fibroblasts. Am J Physiol Cell Physiol. 2004;286:C1089-C1099.

30. Swaney JS, Roth DM, Olson ER, Naugle JE, Meszaros JG, Insel PA. Inhibition of cardiac myofibroblast formation and collagen synthesis by activation and overexpression of adenylyl cyclase. Proc Natl Acad Sci U S A. 2005;102:437-442.

31. Fitzner B, Brocka $P$, Nechutova $H$, et al. Inhibitory effects of interferongamma on activation of rat pancreatic stellate cells are mediated by STAT1 and involve down-regulation of CTGF expression. Cell Signal. 2007;19:782-790.

32. Weng H, Mertens PR, Gressner AM, Dooley S. IFN-gamma abrogates profibrogenic TGF-beta signaling in liver by targeting expression of inhibitory and receptor smads. J Hepatol. 2007;46:295-303.

33. Song E, Chen J, Wang K, et al. Intrasplenic transplantation of syngenic hepatocytes modified by IFN-gamma gene ameliorates hepatic fibrosis in rats. Transpl Int. 2002;15:472-478.

34. Jeong WI, Park O, Radaeva S, Gao B. STAT1 inhibits liver fibrosis in mice by inhibiting stellate cell proliferation and stimulating $\mathrm{NK}$ cell cytotoxicity. Hepatology. 2006;44:1441-1451. 
35. Sakaida I, Uchida K, Matsumura Y, Okita K. Interferon gamma treatment prevents procollagen gene expression without affecting transforming growth factor-beta1 expression in pig serum-induced rat liver fibrosis in vivo. J Hepatol. 1998;28:471-479.

36. Baroni GS, D'Ambrosio L, Curto P, et al. Interferon gamma decreases hepatic stellate cell activation and extracellular matrix deposition in rat liver fibrosis. Hepatology. 1996;23:1189-1199.

37. Shen H, Zhang M, Minuk GY, Gong Y. Different effects of rat interferon alpha, beta and gamma on rat hepatic stellate cell proliferation and activation. BMC Cell Biol. 2002;3:9.
38. Jacobson KA, Gao ZG. Adenosine receptors as therapeutic targets. Nat Rev Drug Discov. 2006;5:247-264.

39. Chan ES, Fernandez P, Merchant AA, et al. Adenosine A2A receptors in diffuse dermal fibrosis: pathogenic role in human dermal fibroblasts and in a murine model of scleroderma. Arthritis Rheum. 2006a;54:2632-2642.

40. Dubey RK, Gillespie DG, Jackson EK. Adenosine inhibits collagen and protein synthesis in cardiac fibroblasts: role of A2B receptors. Hypertension. 1998;31:943-948.

\section{Publish your work in this journal}

The International Journal of Interferon, Cytokine and Mediator Research is an international, peer-reviewed, open-access, online journal. The focus of the journal is to publish original research, reports, editorials, reviews and commentaries on all aspects of interferon, cytokine and mediators of inflammation from labora- tory science to therapeutic indications and clinical studies. The manuscript management system is completely online and includes a very quick and fair peer-review system, which is all easy to use. Visit http://www.dovepress.com/testimonials.php to read real quotes from published authors.

Submit your manuscript here: http://www.dovepress.com/international-journal-of-interferon-cytokine-and-mediator-research-journal 